\title{
YOGA PRENATAL TRIMESTER III DAPAT MEMPERCEPAT LAMA KALA II PERSALINAN PADA IBU PRIMIGRAVIDA
}

\author{
Ratna Dewi Putri1), Husnaini2), Sunarsih ${ }^{3)}$ \\ ${ }^{1}$ Diploma IV Kebidanan Fakultas Kedokteran Universitas Malahayati \\ Email: ratnadewi@malahayati.ac.id \\ ${ }^{2}$ RSUD Pesawaran Lampung \\ Email: husnaini@gmail.com \\ ${ }^{3}$ Diploma III Kebidanan Fakultas Kedokteran Universitas Malahayati \\ Email: sunarsih@malahayati.ac.id
}

\begin{abstract}
Background: The labor process is influenced by power, passage, passanger, helper and psychological factors.Accoding to these factors yoga is an alternative to preparing labor because the exercise technique focuses on muscle control, breathing techniques, relaxation, peace of mind. Preliminary survey at BPM Tri Imawati, SST in January - December 2017 was found 52 (53\%) of primigravida mothers experienced long second stage labor duration and 47 (47\%) of maternal mothers experience normal second stage duration.

The purpose of this study is to know the influence of prenatal yoga exercises Trimester III Against the Second Kala II Labor on Primigravida Mother in Work Area of Puskesmas Metro Center City Metro Lampung Province Year 2018.

MethodsThis type of quantitative research with quasi experimental research method design. The population in this study were 30 mothers of primigravida Trimester III with 30 samples divided into two groups: 15 mothers of primigravida trimester III who followed prenatal yoga exercises and 15 mothers of primigravida trimester III who did not follow prenatal yoga exercises, the sample technique taken is purposive sampling. Data analysis was performed using statistical test using independent $t$ test. The result of the research shows that the mean (mean) of the second stage of labor in the primigravida mother who followed yoga gymnastics is 21.67 minutes with the standard deviation of 7.48 minutes. The mean (mean) duration of second stage of labor in primigravida mother who did not follow yoga gymnastics was 44.67 minutes with a standard deviation of 12.74 minutes.

Conclusion:There is influence of prenatal yoga practice of trimester III on the second stage of labor in primigravida mother. For every pregnant mother is suggested to follow yoga gymnastics as an alternative to delivery, because by following yoga exercises during pregnancy provide mental readiness, help to focus mind, give peace and comfort.
\end{abstract}

Keywords: Prenatal yoga exercises, second stage duration, Primigravida Mother

\section{ABSTRAK}

Latar Belakang: Proses persalinan dipengaruhi oleh faktor power, passage, passanger, penolong dan psikis. Berdasarkan faktor tersebut yoga merupakan salah satu alternatif untuk mempersiapkan persalinan karena teknik latihannya menitik beratkan pada pengendalian otot, teknik pernapasan, relaksasi dan ketenangan pikiran. Pra survey yang dilakukan di Praktik Mandiri Bidan Tri ImawatiSST, pada bulan Januari - Desember tahun 2017 menunjukkanbahwa52 (53\%) ibu primigravida mengalami kala II lama dan 47 (47\%) ibu bersalin yang tidak mengalami kala II lama. 
Tujuan penelitian: Diketahui pengaruh senam yoga prenatal Trimester III Terhadap Lama Kala II Persalinan pada Ibu Primigravida di Wilayah Kerja Puskesmas Metro Pusat Kota Metro Provinsi Lampung Tahun 2018.

Metode: Penelitian kuantitatif dengan desain penelitian metode quasi ekperimentdengan pendekatan two group post test design. Populasi adalah ibu bersalin primigravida Trimester III, sampel 30 ibu terbagi menjadi dua kelompok 15 ibu bersalin primigravida trimester III yang menggikuti senam yoga prenatal dan 15 ibu bersalin primigravida trimester III yang tidak mengikuti senam yoga prenatal, teknik samplingpurposive sampling. Analisis data dilakukan menggunakan uji statistik menggunakan uji t independent.

Hasil penelitian: Rata-rata (mean) lama kala II persalinan pada ibu primigravida yang mengikuti senam yoga adalah 21,67 menit dengan standar deviasi sebesar 7,48 menit. Rata-rata (mean) lama kala II persalinan pada ibu primigravida yang tidak mengikuti senam yoga adalah 44,67 menit dengan standar deviasi sebesar 12,74 menit.

Kesimpulan : Ada pengaruh senam yoga prenatal trimester III terhadap lama kala II persalinan pada ibu primigravida ( $p$-value $=0,000)$. Ibu hamil trimester III dapat melaksanakan senam yoga sebagai alternatif persiapan persalinan, karena membantu kesiapanmental, membantu memusatkan pikiran, memberi ketenangan dankenyamanan sehingga mempercepat lama kala II.

Kata Kunci: Senam yoga prenatal, Lama Kala II, Persalinan, Ibu Primigravida

\section{PENDAHULUAN}

Proses persalinan pada ibu bersalin normal berlangsung dalam waktu kurang dari 24 jam, dimana terbagi dalam empat kala. Kala I pada fase laten berlangsung selama delapan jam dan fase aktif berlangsung selama tujuh jam. Persalinan kala II biasanya berlangsung dua jam pada primi dan satu jam pada multigravida, kala III berlangsung kurang dari 30 menit sedangkan kala IV dimulai dari saat lahirnya plasenta sampai dua jam pertama postpartum (Sumarah, 2009).

Proses persalinan dipengaruhi oleh beberapa faktor yang disebut $5 \mathrm{P}$, yaitu power, passage, passangger, penolong, dan psikis. Lama persalinan dapat disebabkan oleh banyak faktor, namun yang prinsip adalah kontraksi tidak adekuat, faktor janin (malpresentasi, malposisi, janin besar) dan faktor jalan lahir. Kontraksi yang tidak adekuat dan faktor janin dapat menyebabkan persalinan kala II menjadi memanjang(Sofyan, 2011).

Kala II lama adalah ketika serviks mencapai dilatasi penuh, jangka sampai terjadinya kelahiran tidak boleh melewati 2 jam pada primigravida dan 1 jam pada multigravida. Pengalaman menunjukkan bahwa setelah batas waktu ini, morbiditas maternal dan fetal akan meningkat. Sekitarnya terjadi gawat janin atau ibu, tindakan segera merupakan indikasi. Banyak faktor yang menyebabkan kala II lama anatara lain :disproporsi sefalopelvik, malpresentasi dan malposisi, persalinan tidak efektif, serta distosia jaringan lunak. (Oxorn, 2010).

Persalinan yang diikuti dengan kejadian memanjangnya waktu pada kala II mempunyai dampak kepada ibu dan janin. Dampak yang akan terjadi pada ibu dengan kala II lama yaitu akan terjadi kelelahan sampai mengakibatkan dehidrasi, infeksi pada ibu terutama jika sudah terjadi pecahnya selaput ketuban, hingga perdarahan karena atonia uteri, dan ruptur uteri. Dampak dari kala II lama ini menimbulkan morbiditas tinggi pada ibu bahkan dapat menjadi penyebab mortalitas pada ibu dan janin karena penanganan yang tidak adekuat pada ibu bersalin dengan kala II lama. Pada ibu bersalin dengan kala II lama mungkin akan dilakukan induksi persalinan apabila ibu dan janin dalam kondisi baik, proses induksi ini yang juga dapat menimbulkan kesakitan pada ibu karena kontraksi buatan setelah kontraksi alami telah dirasakan ibu dengan waktu yang lama. Apabila induksi gagal, persalinan dengan cara seksio sesarea juga dapat dilakukan dengan pertimbangan kondisi janin dan juga ibu (Aulia, 2010)

Ada beberapa cara tindakan pencegahan selama kehamilan agar ibu dan janin berada dalam kondisi sehat dan nantinya terjadi proses persalinan normal yaitu olahraga jalan pagi, bersepeda statis, 
aerobic, senam air, menari, dan yoga. Senam hamil memiliki beberapa metode latihan diataranya yaitu yoga, pilates, kegel, hypnotherapy (Krisnadi. 2010).

Yoga adalah cara yang baik untuk mempersiapkan persalinan karena teknik latihannya menitik beratkan pada pengendalian otot, teknik pernapasan, relaksasi, ketenangan pikiran. Yoga sangat berperan dalam mempersiapkan proses kelahiran ibu hamil dikarenakan perubahan fisik dan perubahan psikis yang dialaminya (Yuliarti, 2010).

Yoga juga bermanfaat dalam melatih dan menguasai teknik pernafasan yang berperan penting selama kehamilan dan proses persalinan. Kegunaan dari latihan dasar pernafasan yaitu melatih ketegangan, mempercepat sirkulasi darah serta mencukupi kebutuhan oksigen bagi ibu dan janinnya. Manfaat yang tak kalah pentingnya yaitu memperkuat dan mempertahankan elastisitas otototot dinding perut, ligamentum, otot-otot dasar pangul dan otot paha bagian dalam, dengan demikian proses persalinan dapat dikuasai. Proses relaksasi akan sempurna dengan mengontrol kontraksi dan relaksasi yang diperlukan untuk mengatasi ketegangan atau rasa sakit saat proses persalinan. Salah satu latihan menguatkan dan mempertahankan elastisitas adalah latihan menguatkan otot dasar panggul yang kegunaannya adalah melemaskan otot dasar panggul yang kuat dalam keadaan yang santai. Pada saat mengejan otot akan mengendur secara aktif sehingga kepala bayi akan keluar dengan mudah, dengan demikian akan memperlancar dalam proses persalinan (Irmawati, 2014).

Berdasarkan pra survey pada bulan februari 2018 di wilayah kerja Puskesmas Metro Pusat di dapatkandata PMB Tri Imawati,SST, dengan jumlah ibu bersalin primigravida pada tahun 2017 yaitu

\section{HASIL PENELITIAN DAN PEMBAHASAN}

\section{Karakteristik Responden}

Tabel 1 Karakteristik Responden pada kelompok Yoga Prenatal dan kelompok kontrol

\begin{tabular}{lcc}
\hline Karakteristik & Mengikuti Yoga & Tidak Mengikuti Yoga \\
\hline & Umur \\
\hline $18-25$ tahun & 5 & 10 \\
$26-30$ tahun & 10 & 5 \\
\hline \multicolumn{3}{c}{ Pekerjaan } \\
\hline
\end{tabular}

sejumlah 98ibu bersalin dimana terdapat $52(53 \%)$ ibu primigravida yang mengalami kala II lama dan terdapat $47(47 \%)$ ibu bersalin yang tidak mengalami kala II lama. PMB Tri Imawati, SST merupakan praktik mandiri bidan yang secara rutin dan terstandar melakukan prenatal yoga. Penelitian ini bertujuan untuk mengetahui Pengaruh Senam Yoga Prenatal Trimester III Terhadap Lama Kala II Persalinan Pada Ibu Primigravida Wilayah Kerja Puskesmas Metro Pusat Kota Metro Provinsi Lampung Tahun 2018.

\section{METODE PENELITIAN}

Penelitian ini merupakan penelitian kuantitatif dengan desain Two Group Post Test dimana dalam rancangan ini menggunakan kelompok kontrol sebagai garis dasar untuk dibandingkan dengan kelompok yang diberikan perlakuan (Nasir, 2011)

Populasi merupakan keseluruhan objek penelitian atau objek yang diteliti (Notoatmodjo, 2010).Populasi dalam penelitian adalah ibu bersalin primigravida. Teknik sampling dalam penelitian ini adalah purposive sampling. Sampel dalam penelitian ini berjumlah 30 ibu bersalin primigravida di Wilayah Kerja Puskesmas Metro Pusat yang terbagi menjadi dua lokasi yaitu PMB Tri Imawati SST dan PMB Kiswari, SST. Sampel dibagi menjadi dua kelompok yaitu 15 ibu bersalin primigravida yang menggikuti senam yoga prenatal dan 15 ibu bersalin primigravida yang tidak mengikuti senam yoga prenatal.

Analisa data dalam penelitian ini menggunakan uji beda dua mean, dengan menggunakan paired t-test atau uji t berpasangan. Uji-t berpasangan (paired t-test) (Sugiyono,2006). 


\begin{tabular}{lll}
$\begin{array}{l}\text { Ibu rumah tangga } \\
\text { Ibu bekerja }\end{array}$ & 14 & 12 \\
\cline { 2 - 3 } & 1 & 3 \\
\hline Normal & IMT & 10 \\
Gemuk & 8 & 2 \\
Berlebih & 4 & 3 \\
\hline
\end{tabular}

Hasil Penelitian

Tabel 2 Lama Kala II pada kelompok Yoga Prenatal dan Kelompok Kontrol

\begin{tabular}{ccccccc}
\hline Lama kala II & N & Min & Max & Mean & Std Dev & P value \\
\hline Yoga Prenatal & 15 & 10 & 40 & 21,67 & 7,48 & \multirow{2}{*}{0,000} \\
Tidak Yoga & 15 & 15 & 60 & 44,67 & 12,74 & \\
\hline
\end{tabular}

\section{PEMBAHASAN}

\section{Lama Kala II Pada Ibu yang Mengikuti Yoga Prenatal}

Berdasarkan hasil penelitian, diketahui ratarata (mean) lama kala II persalinan pada ibu primigravida yang mengikuti senam yoga adalah 21,67 menit dengan standar deviasi sebesar 7,48 menit.

Kala II lama adalah ketika serviks mencapai dilatasi penuh, jangka sampai terjadinya kelahiran tidak boleh melewati 2 jam pada primigravida dan 1 jam pada multigravida. Pengalaman menunjukkan bahwa setelah batas waktu ini, morbiditas maternal dan fetal akan meningkat. Sekitarnya terjadi gawat janin atau ibu, tindakan segera merupakan indikasi. Banyak faktor yang menyebabkan kala II lama anatara lain: disproporsi sefalopelvik, malpresentasi dan malposisi, persalinan tidak efektif, serta distosia jaringan lunak (Oxorn, 2010).

\section{Lama Kala II Pada Ibu yang tidak Mengikuti Senam Yoga}

Berdasarkan hasil penelitian, diketahui ratarata (mean) lama kala II persalinan pada ibu primigravida yang tidak mengikuti senam yoga adalah 44,67 menit dengan standar deviasi sebesar 12,74 menit.

Berdasarkan uraian di atas, maka diketahui rata-rata (mean) lama kala II persalinan pada ibu primigravida yang tidak mengikuti senam yoga lebih lama dibandingkan dengan ibu yang mengikuti senam yoga. Hal ini juga sesuai dengan teori yang dikemukakan oleh Wiadnyana (2011) yang mengatakan bahwa wanita hamil yang melakukan yoga secara rutin akan memperoleh keuntungan yaitu memperlancar proses persalinan, mengurangi section caesaria, dan mengurangi terjadinya gawat janin padda waktu persalinan.

\section{Pengaruh Yoga Prenatal terhadap lama kala II Persalinan}

Berdasarkan hasil uji T Test diketahui ada pengaruh senam yoga prenatal trimester III terhadap lama kala II persalinan pada ibu primigravida ( $p$ value : 0,000 ) ibu primigravida yang melakukan yoga prenatal rata rata mengalami kala II selama 21, 67 menit yang mana lebih cepat bila dibandingkan dengan ibu yang tidak yoga.

Ada beberapa cara tindakan pencegahan selama kehamilan agar ibu dan janin berada dalam kondisi sehat dan nantinya terjadi proses persalinan normal yaitu olahraga jalan pagi, bersepeda statis, aerobic, senam air, menari, dan yoga. Senam hamil memiliki beberapa metode latihan diataranya yaitu yoga, pilates, kegel, hypnotherapy (Krisnadi. 2010).

Yoga adalah cara yang baik untuk mempersiapkan persalinan karena teknik latihannya menitik beratkan pada pengendalian otot, teknik pernapasan, relaksasi, ketenangan pikiran. Yoga sangat berperan dalam mempersiapkan proses kelahiran ibu hamil dikarenakan perubahan fisik dan perubahan psikis yang dialaminya (Yuliarti, 2010).

Yoga juga bermanfaat dalam melatih dan menguasai teknik pernafasan yang berperan penting selama kehamilan dan proses persalinan. Kegunaan dari latihan dasar pernafasan yaitu 
melatih ketegangan, mempercepat sirkulasi darah serta mencukupi kebutuhan oksigen bagi ibu dan janinnya. Manfaat yang tak kalah pentingnya yaitu memperkuat dan mempertahankan elastisitas otototot dinding perut, ligamentum, otot-otot dasar pangul dan otot paha bagian dalam, dengan demikian proses persalinan dapat dikuasai. Proses relaksasi akan sempurna dengan melakukan kontraksi dan relaksasi yang diperlukan untuk mengatasi ketegangan atau rasa sakit saat proses persalinan. Salah satu latihan menguatkan dan mempertahankan elastisitas adalah latihan menguatkan otot dasar panggul yang kegunaannya adalah melemaskan otot dasar panggul yang kuat dalam keadaan yang santai. Pada saat mengejan otot akan mengendur secara aktif sehingga kepala bayi akan keluar dengan mudah, dengan demikian akan memperlancar dalam proses persalinan (Irmawati, 2014).

Faktor utama yang mempengaruhi proses persalinan diantaranya yaitu power (kekuatan), passage (keadaan panggul) dan passanger (keadaan janin). Ibu yang memiliki kekuatan fisik yang bagus akan lebih mudah dalam proses persalinan, keadaan panggul yang besar mampu melancarkan persalinan secara normal, selain itu kondisi janin yang terdapat di dalam rahim juga mempengaruhi proses persalinan.

Yoga prenatal bermanfaat dalam melatih dan menguasai teknik pernafasan yang berperan penting selama kehamilan dan proses persalinan. Kegunaan dari latihan dasar pernafasan yaitu melatih ketegangan, mempercepat sirkulasi darah serta mencukupi kebutuhan oksigen bagi ibu dan janinnya. Manfaat yang tak kalah pentingnya yaitu memperkuat dan mempertahankan elastisitas otototot dinding perut, ligamentum, otot-otot dasar pangul dan otot paha bagian dalam, dengan demikian proses persalinan dapat dikuasai. Proses relaksasi akan sempurna dengan melakukan kontraksi dan relaksasi yang diperlukan untuk mengatasi ketegangan atau rasa sakit saat proses persalinan. Salah satu latihan menguatkan dan mempertahankan elastisitas adalah latihan menguatkan otot dasar panggul yang kegunaannya adalah melemaskan otot dasar panggul yang kuat dalam keadaan yang santai.Pada saat mengejan otot akan mengendur secara aktif sehingga kepala bayi akan keluar dengan mudah, dengan demikian akan memperlancar dalam proses persalinan (Irmawati, 2014).

Hasil penelitian ini sejalan dengan peneltian Sarwendah, 2014 ( Hubungan Antara Yoga Prenatal Dengan Proses Persalinan Pada Ibu Bersalin Di BPM Harti Mustagim Sumowono Kabupaten Semarang Tatun 2014.) menunjukkan $97,1 \%$ ibu yang rutin mengikuti yoga prenatal bersalin normal. ( Pvalue $0,003<\alpha$ )

Hasil penelitian ini juga sejalan dengan penelitian Agustiana, Dewi (2013), Hubungan senam yoga ibu hamil dengan lama persalinan kala II pada ibu bersalin primigravida di BPS Prita Salatiga menunjukan hasil penelitian bahwa ibu hamil yang mengikuti senam yoga rata-rata 2-3 kali selama kehamilan dan lama persalinan kala II ratarata 43,88 menit, nilai $p$ value sebesar 0,0001 berarti ada hubungan senam yoga ibu hamil dengan lama persalinan kala II pada ibu bersalin primigravida, dan nilai $r=-0,0685$ yang berarti senam juga memiliki kolerasi yang kuat dengan lama proses persalinan kala II dengan arah kolerasi negatif dimana semakin banyak melakukan senam yoga semakin singkat waktu persalinan kala II

Narendra (2005) dalam penelitiannya di India mengenai efektifitas yoga pada luaran persalinan menemukan bahwa kelompok yang berlatih yoga mengalami lebih sedikit persalinan prematur, kejadian retardasi pertumbuhan intrauterin yang rendah, dan lebih sedikit kejadian hipertensi yang diinduksi karena kehamilan dibandingkan dengan kelompok yang tidak berlatih yoga. Dalam penelitian ini, tidak ada masalah atau kesulitan yang dikaitkan dengan berlatih yoga.

Wanita hamil yang melakukan yoga secara rutin akan memperoleh keuntungan yaitu memperlancar proses persalinan, mengurangi kemungkinan dilakukan sectio caesaria, dan mengurangi terjadinya gawat janin padda waktu persalinan. Dimana lama kala II persalinan pada ibu primigravida yang mengikuti senam yoga akan lebih cepat dibandingkan dengan ibu primigravida yang tidak mengikuti senam yoga.

\section{KESIMPULAN}


Rata-rata (mean) lama kala II persalinan pada ibu primigravida yang mengikuti senam yoga di wilayah Kerja Puskesmas Metro Pusat Kota Metro Provinsi Lampung tahun 2018 adalah 21,67 menit dengan standar deviasi sebesar 7,48 menit. Rata-rata (mean) lama kala II persalinan pada ibu primigravida yang tidak mengikuti senam yoga di wilayah Kerja Puskesmas Metro Pusat Kota Metro Provinsi Lampung tahun 2018 adalah 44,67menit dengan standar deviasi sebesar 12,74 menit. Ada pengaruh senam yoga prenatal trimester III terhadap lama kala II persalinan pada ibu primigravida wilayah kerja Puskesmas Metro Pusat Kota Metro Provinsi Lampung tahun 2018 dengan $p$-value $=0,000$.

\section{SARAN}

Bagi setiap ibu hamil trimester III disarankan mengikuti senam yoga sebagai alternatif persiapan persalinan,karena dengan mengikuti senam yoga masa kehamilan memberikan kesiapan mental, membantu memusatkan pikiran, memberi ketenangan dan kenyamanan. Selain itu dengan senam yoga otot-otot yang berhubungan dengan persalinan akan terlatih sehingga proses berjalan lancar. Apabila ibu tidak mengikuti senam yoga ibu dapat mengikuti kelas ibu untuk melakukan senam hamil

Petugas kesehatan (bidan) sebagai tenaga kesehatan terdepan diharapkan dapat memotivasi ibu hamil untuk melakukan senam yoga sebagai alternatif persiapan persalinan, selain itu bidan diharapkan dapat mempelajari senam yoga sehingga dapat mengajarkan senam yoga pada ibu hamil

\section{DAFTAR PUSTAKA}

Anik, M. (2010). Ilmu kesehatan anak dalam kebidanan. Jakarta: TIM

Aulia, H., \& Hindun, S. (2010). Pengaruh Senam Hamil Terhadap Proses Persalinan Normal Di Klinik YK Madira Palembang. Jurnal Kedokteran dan Kesehatan Fakultas Kedokteran UNSRI, (1), 2782-2787.

Agustiana, Dewi. (2013). Hubungan Senam Yoga Ibu Hamil dengan Lama Persalinan Kala II Pada Ibu Bersalin Primi Gravida di
BPS Prita Yusita Salatiga Periode Tahun 2011 - 2012. Perpusnwu.web.id

Bobak, L. J. (2004). Buku Ajar: Keperawatan dan Maternitas Edisi 4.

Cunningham, G.F., Gant, N.F., Leveno, K.J., Gilstrap, L.C., Hauth, J.C., \&Wenstrom, K.D, (2005).Obstetri Williams. Jakarta: EGC.

Dempsey, P, A \&Dempsey, A, D (2002). Riset Keperawatan: Buku Ajar \& Latihan. Edisi 4. Jakarta: EGC.

Dinas Kesehatan Provinsi Lampung (2016).Profil Kesehatan Provinsi Lampung Tahun 2016. Bandar Lampung.

Doenges, M. E., \& Moorhouse, M. F. (2001). Rencana Perawatan Maternal/Bayi Pedoman Untuk Perencanaan Dan Dokumentasi Perawatan Klien. Jakarta: EGC.

Irmawati (2014). Tetap Tersenyum Saat Melahirkan. Penerbit : Media Pressindo

JNPK-KR(2017) Asuhan PersalinanNormal2017 Pelatihan Klinik Asuhan Persalinan Normal, Jaringan Nasional Pelatihan KlinikKesehatan Reproduksi, Jakarta,

Krisnadi, S. R. (2010). Sinopsis Yoga Untuk Kehamilan: Sehat, Bahagia Dan Penuh Makna.

Manuaba, I. B. G. (2006). IImu kebidanan, penyakit kandungan \& keluarga berencana untuk pendidikan bidan.

Narendra S, Nagarathna R, Narenrdran V, Gunasheela S, Nagendra H R (2005). Efficacy of Yoga on Pregnancy Outcome. The journal of Alternative and Complementary Midicine, 11 (2).

Nasir, A., Muhith, A., \& Ideputri, M. E. (2011). Buku ajar metodologi penelitian kesehatan. Yogyakarta: Nuha Medika, 185210.

Oxorn, H., \& Forte, W. R. (2010). IImu kebidanan: patologi dan fisiologi persalinan. Penerbit Andi.

Prawirohardjo, S. (2009). IImu Kebidanan .Jakarta. Yayasan Bina Pustaka.

Sofian, A. (2011). Rustam Mochtar Sinopsis Opstetri: Obstetri Operatif, Obstetri Sosial, Edisi 3 Jilid 2. 
Soekidjo, N. (2010). Metodologi penelitian kesehatan. Jakarta: Rineka Cipta, 50.

Sylvia, V. (2010). Anatomi Dan Fisiologi Terapan Dalam Kebidanan Edisi: $3 .$.

Sugiyono, D. R. (2006). Statistika untuk penelitian. Bandung: CV. Alfabeta.

Sumarah, W. Wiyati.(2009). Perawatan Ibu Bersalin(Asuhan Kebidanan pada Ibu Bersalin). Jogjakarta: Fitramaya.
Wiadnyana, M. S. (2011). The power of yoga for pregnancy and post-pregnancy. PT Gramedia Pustaka Utama.

Yuliarti, N. (2010). Keajaiban ASI-makanan terbaik untuk kesehatan, kecerdasan dan kelincahan si kecil. Penerbit Andi. 